\title{
AGRO-ECONOMIC EFFICIENCY OF THE INTERCROPPING OF CARROT X COWPEA-VEGETABLE UNDER DIFFERENT SPATIAL ARRANGEMENTS AND POPULATION DENSITIES ${ }^{1}$
}

\author{
GIORGIO MENDES RIBEIRO ${ }^{2 *}$, FRANCISCO BEZERRA NETO ${ }^{2}$, JAILMA SUERDA SILVA DE LIMA ${ }^{2}$, MAIELE \\ LEANDRO DA SILVA ${ }^{3}$, AURÉLIO PAES BARROS JÚNIOR ${ }^{2}$, ELIZANGELA CABRAL DOS SANTOS ${ }^{2}$
}

\begin{abstract}
The objective of this study was to evaluate the agro-economic efficiency of the intercropping of carrot with cowpea-vegetable under different spatial arrangements and population densities in the semi-arid conditions of the Brazilian Northeast. The study was conducted at the "Rafael Fernandes" Experimental Farm of the Universidade Federal Rural do Semi-Árido (UFERSA) during the period July 2013 to February 2014. The experimental design was of randomized complete blocks with four replications and treatments arranged in a $3 \times 4$ factorial scheme, where the first factor consisted of spatial arrangements $(2: 2 ; 3: 3$ and $4: 4)$ and the second factor by population densities of cowpea-vegetables $(100,80,60$ and $40 \%$ of the recommended population in sole crop [RPSC]). All treatments were fertilized with roostertree (Calotropis procera [Ait.] R.Br.), which is a spontaneous species of the Caatinga biome. The indices of agronomic efficiency of the intercropping systems assessed were: land equivalent ratio, productive efficiency index and score of the canonical variable. The following economic indicators were also evaluated: gross income, net income, rate of return and profit margin. The agro-economic efficiency of the intercropping system of carrot with cowpeavegetable was influenced by the spatial arrangements, with the 2:2 arrangements standing out from the others. The greatest agro-economic efficiency of the intercropping of carrot with cowpea-vegetable was obtained in the population density of $100 \%$ of the RPSC when the value of the productive efficiency index was 0.75 .
\end{abstract}

Keywords: Daucus carota. Vigna unguiculata. Intercropping system.

\section{EFICIÊNCIA AGROECONÔMICA DO CONSÓRCIO DE CENOURA X CAUPI-HORTALIÇA SOB DIFERENTES ARRANJOS ESPACIAIS E DENSIDADES POPULACIONAIS}

RESUMO - O objetivo deste estudo foi avaliar a eficiência agroeconômica do consórcio de cenoura com caupi-hortaliça sob diferentes arranjos espaciais e densidades populacionais nas condições semiáridas do Nordeste brasileiro. O estudo foi realizado na Fazenda Experimental "Rafael Fernandes" da Universidade Federal Rural do Semi-Árido (UFERSA) no período de julho 2013 a fevereiro de 2014. O delineamento experimental adotado foi de blocos completos casualizados com quatro repetições, com os tratamentos arranjados em um esquema fatorial $3 \times 4$, sendo o primeiro fator constituído pelos arranjos espaciais $(2: 2 ; 3: 3$ e $4: 4)$ e o segundo fator pelas densidades populacionais do caupi-hortaliça $(100 \%, 80 \%, 60 \%$ e $40 \%$ da população recomendada no cultivo solteiro - PRCS). Todos os tratamentos foram fertilizados com flor-de-seda (Calotropis procera (Ait.) R.Br.), que é uma espécie espontânea do bioma Caatinga. Os índices de eficiência agronômica dos sistemas consorciados avaliados foram: índice de uso eficiente da terra, índice de eficiência produtiva e escore da variável canônica. Foram também avaliados os seguintes indicadores econômicos: renda bruta, renda líquida, taxa de retorno e índice de lucratividade. A eficiência agroeconômica do sistema consorciado de cenoura com caupi-hortaliça foi influenciada pelos arranjos espaciais, com o arranjo 2:2 sobressaindo-se dos demais. A maior eficiência agroeconômica do consórcio de cenoura com caupi-vegetal foi obtida na densidade populacional de $100 \%$ da PRCS quando o valor do índice de eficiência produtiva foi de 0,75 .

Palavras-chave: Daucus carota. Vigna unguiculata. Sistema consorciado.

\footnotetext{
"Corresponding author

${ }^{1}$ Received for publication in $06 / 02 / 2016$; accepted in $02 / 15 / 2017$

Paper extracted from the doctoral thesis of the first author.

${ }^{2}$ Department of Plant Science, Universidade Federal Rural do Semi-Árido, Mossoró, RN, Brazil; giorgio@ufersa.edu.br, bezerra@ufersa.edu.br, jailma@ufersa.edu.br, aurelio.barros@ufersa.edu.br, elizangelacabral@ufersa.edu.br.

${ }^{3}$ Universidade Estadual de Mato Grosso do Sul, Aquidauana, MS, Brazil; maiele_engenharia@yahoo.com.br.
} 


\section{INTRODUCTION}

The production of vegetable crops is characterized as a highly intensive activity in terms of soil, water, inputs and labor, and is practiced mostly by small family farms as a means of subsistence, or in the small-scale commercialization of surplus production. Intercropping systems are among the agricultural practices that are successfully used by vegetable producers, and present gains in productivity, and nutritional, economic and environmental value (MONTEZANO; PEIL, 2006; ALMEIDA et al., 2015).

It is known, however, that the efficiency of the intercropping directly depends on the management and cultures involved (PORTO et al., 2011). Proper management of the factors of production, such as the spatial arrangement of crops, and population and planting density, among others, can reduce the competition for resources and increase the efficiency of the system. These factors, when properly managed, can bring ecological and economic benefits to the activity as a result of the complementarity nature of the species involved, increasing production when compared to monoculture or chemical, physical and biological soil enrichment (BATISTA et al., 2016; GRISA; SCHNEIDER, 2008).

In the vegetable crop production system, capital involvement, skilled labor and knowledge are 'well-developed', facilitating high-quality and consistent production at low cost (COSTA, 2006). This system involves different aspects of the production chain, such as the organic, infrastructure and trade, and must be managed competently for good results and produce with low economic and environmental costs (CECILIO FILHO et al., 2015).

Several indices are used both in the agronomic evaluation of the biological productivity and in the economic efficiency of the intercropping systems (BEZERRA NETO et al., 2007; BEZERRA NETO et al., 2010; BEZERRA NETO; GOMES; OLIVEIRA, 2007). However, the land equivalent ratio (LER) is the index most frequently used by researchers in the area of intercropping. The use of this index has some advantages: it can be used as an index of biological efficiency to evaluate the effects of several agronomic variables (fertility levels, spacing and densities, cultivars, establishment times and crop combinations, etc.) in the intercropping system in one place, or as a productivity index to compare a variety between intercropping systems in several places (BEZERRA NETO et al., 2012). The land equivalent ratio provides a basis for crop standardization in relation to sole cropping, so yields of the component crops can be added to form the combined yields (ALFA; MUSA, 2015). These authors argue that one should avoid the advantage of intercropped crops only by taking into account the basic values of this index.
Other indexes can be used to determine the agroeconomic efficiency of the intercropping systems, such as the productive efficiency index and the score of the canonical variable $\mathrm{Z}$.

There are also some economic indicators that are used to evaluate the productivity and efficiency of the intercropped systems, among them we can highlight: gross income, net income, rate of return and profit margin.

This study aimed to evaluate the agroeconomic efficiency of the intercropping of carrot and cowpea-vegetable under different spatial arrangements and population densities.

\section{MATERIAL AND METHODS}

The experiment was carried out at the Rafael Fernandes Farm, which belongs to the Universidade Federal Rural do Semi-Árido (UFERSA), located in the district of Alagoinha, $20 \mathrm{~km}$ away from the municipality of Mossoró, Brazil ( $5^{\circ} 11$ 'S and $37^{\circ} 20^{\prime} \mathrm{W}$; altitude, $18 \mathrm{~m}$ ), from July 2013 to February 2014. The climate of the region is semi-arid and, according to the Köppen climate classification scheme, designated as 'BShw', dry and very hot, with two seasons: a dry season, which usually runs from June to January; and a rainy season, from February to May (ALMEIDA et al., 2015). During the experimental period, the mean temperature was $27^{\circ} \mathrm{C}$; the minimum and maximum means were of $22^{\circ} \mathrm{C}$ and $32^{\circ} \mathrm{C}$, respectively; mean air relative humidity was $67 \%$; mean wind speed was $4 \mathrm{~m} \mathrm{~s}^{-1}$; mean radiation was $23.39 \mathrm{mjm}^{2}$; rainfall was $0 \mathrm{~mm}$; mean atmospheric pressure was $1009 \mathrm{hPa}$ and mean dew point temperature was $19^{\circ} \mathrm{C}$.

The soil of the experimental area was a dystrophic yellow-red oxisol (FREIRE FILHO et al., 2009). At the site of the experiment, soil simple samples were collected using a Dutch auger at 0-20 cm depth and then homogenized to obtain a composite sample, which was sent for analysis at the Laboratory of Soil Fertility and Plants Nutrition at the Department of Environmental and Technological Sciences of the UFERSA. The results were as follows: $\mathrm{pH}$ (water) $=7.09$; Organic matter $(\mathrm{OM})=11.5 \mathrm{mg} \mathrm{dm}^{-3} ; \mathrm{N}=0.04 \mathrm{~g} \mathrm{~kg}^{-1}$;

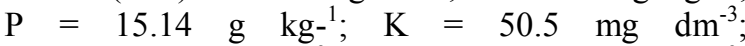
$\mathrm{Na}=4.1 \mathrm{mg} \mathrm{dm} ; \mathrm{Ca}=1.84 \mathrm{cmol}_{\mathrm{c}} \mathrm{dm}^{-3}$; $\mathrm{Mg}=1.39 \mathrm{cmol}_{\mathrm{c}} \mathrm{dm}^{-3}$ and Cation-exchange capacity $(\mathrm{CEC})=3.38 \mathrm{cmol}_{\mathrm{c}} \mathrm{dm}^{-3}$.

A randomized complete block design with treatments arranged in a $3 \times 4$ factorial scheme with four replications was used. The first factor consisted of three spatial arrangements (2: 2, 3: 3, and 4:4), which correspond to rows of carrot (Brasília) alternated with rows of cowpea-vegetable (BRS Itaim), and the second factor of the population densities (40,60, 80 and $100 \%$ of the recommended population in sole crops [RPSC]). 
The intercropped system was established in alternating strips of the component cultures, such that $50 \%$ of the area was for the carrot and $50 \%$ for the cowpea-vegetable, and where the plots consisted of two, three and four rows of carrots alternated with two, three and four rows of cowpea flanked by two border-rows of carrot on one side and two border-rows of cowpea on the other side, thus constituting the lateral borders. The total areas of the plots were $2.40 \mathrm{~m}^{2}, 3.00 \mathrm{~m}^{2}$ and $3.60 \mathrm{~m}^{2}$, with harvest areas of $1.00 \mathrm{~m}^{2}, 1.50 \mathrm{~m}^{2}$ and $2.00 \mathrm{~m}^{2}$, respectively.

In each block single plots of the carrot and cowpea crops were planted in order to obtain the efficiency indices of each crop and of the intercropping system. The single crop of each vegetable was established through the planting of six lines per plot, with a total area of $1.44 \mathrm{~m}^{2}$ and a harvest area of $0.80 \mathrm{~m}^{2}$, with spacing of $0.20 \mathrm{~m} \times 0.10 \mathrm{~m}$ for the carrot crop and a total area of $3.60 \mathrm{~m}^{2}$ and a harvest area of $2.00 \mathrm{~m}^{2}$, with spacing of $0.50 \mathrm{~m} \times 0.10 \mathrm{~m}$ for the cowpea. The harvest areas consisted of central rows of the plot plants, excluding the first and last plants of each row, which were used as a border. The plant population recommended for cowpea-vegetable for single-cropping in the region is 200,000 plants (FREIRE FILHO et al., 2009) and for the carrot is 500,000 ha ${ }^{-1}$ plants (OLIVEIRA et al., 2012).

The soil preparation consisted of mechanical cleaning of the area with the aid of a tractor with a coupled plow, followed by a harrowing and lifting of the beds. Solarization using transparent plastic of 30-micron 'Vulcabrilho Bril Fles' was carried out for 57 days to reduce the soil phytopathogen population, which would affect crop productivity.

A green manuring with roostertree was performed in all the experimental plots and the collection of this manure was carried out in the native vegetation of the urban perimeter Mossoró-Apodi, crushed into pieces $2-3 \mathrm{~cm}$ in length and left to dry at room temperature until becoming hay, and subsequently being stored with a moisture content of $8.3 \%$. Samples of this green manure were randomly collected for quantification of nutrient contents, and the chemical composition was: $15.3 \mathrm{~g} \mathrm{~kg}^{-1} \mathrm{~N} ; 4.0 \mathrm{~g} \mathrm{~kg}^{-1} \mathrm{P} ; 15.7 \mathrm{~g} \mathrm{~kg}^{-1} \mathrm{~K}$; $9.3 \mathrm{~g} \mathrm{~kg}^{-1} \mathrm{Ca}$ and $7.03 \mathrm{~g} \mathrm{~kg}^{-1} \mathrm{Mg}$, with a carbon/ nitrogen ratio of $25: 1$.

Two incorporations of the green manure were carried out in the monocropping and intercropping plots of $51 \mathrm{t} \mathrm{ha}^{-1}$ (SILVA, 2014), with $40 \%$ of the roostertree being incorporated in all plots at 20 days before sowing of the component cultures and the remaining $60 \%$ being incorporated at 40 days, after planting the carrot and the cowpea.

The sowing of the carrot and cowpea-vegetable occurred on October 22, 2013, in holes approximately $3-\mathrm{cm}$ deep, with two to three seeds per hole for the carrot and two seeds for the cowpea. The thinning of the cowpea and carrot was done at 9 and 20 days after planting, respectively. One week before harvesting, 20 plants were randomly identified in each experimental plot to be used to obtain the data.

A micro sprinkler irrigation system was used, with two daily irrigation shifts, one in the morning and one in the afternoon, providing a daily water sheet of approximately $8 \mathrm{~mm}$ in order to maintain soil moisture between $50 \%$ and $70 \%$ of the field capacity (PORTO et al., 2011). Weed control was performed by manual weeding 15,30 and 35 days after sowing.

The carrot harvest occurred on February 3, 2014 (105 days after sowing). Harvesting of cowpea occurred on December 17, 23 and 27, 2013 (57, 63 and 67 days after sowing, respectively).

In order to evaluate the efficiency of the intercropping system, the following indexes were calculated: Land equivalent ratio (LER), productive efficiency index (PEI) and canonical variable score (Z). expression:

The LER was obtained by the following

$\operatorname{LER}=\left(\mathrm{Y}_{\mathrm{ccv}} / \mathrm{Y}_{\mathrm{csc}}\right)+\left(\mathrm{Y}_{\mathrm{cvc}} / \mathrm{Y}_{\mathrm{cvsc}}\right)$, where:

$\mathrm{Y}_{\mathrm{ccv}}=$ Commercial productivity of carrot roots in intercropping with cowpea-vegetable;

$\mathrm{Y}_{\mathrm{csc}}=$ Commercial productivity of carrot roots in sole crop;

$\mathrm{Y}_{\mathrm{cvc}}=$ Productivity of green grains of cowpea-vegetable in intercropping with carrot;

$\mathrm{Y}_{\mathrm{cvsc}}=$ Productivity of green grains of cowpea-vegetable in sole crop.

In the calculation of the PEI of each treatment, we used the Data Envelopment Analysis (DEA) model with constant returns to the scale, since there was no significant difference in the scales. The model has a mathematical formulation: Xik is the input $\mathrm{i}$ value $(\mathrm{i}=1, \ldots, \mathrm{s})$ for treatment $\mathrm{k}$ $(k=1, \ldots, n)$; Yjk is the output $j$ value $(j=1, \ldots, r)$ for treatment $\mathrm{k}$; vi and uj are the weights attributed to inputs and outputs, respectively; and $\mathrm{O}$ is the treatment being analyzed.

$$
\begin{aligned}
& \operatorname{Max} \sum_{i=1}^{r} v_{i} x_{i o} \\
& \sum_{j=1}^{s} u_{j} y_{j o}=1 \\
& \sum_{j=1}^{s} u_{j} y_{j k}-\sum_{i=1}^{r} v_{i} x_{i k} \leq 0, \mathrm{k}=1, \ldots, \mathrm{n} \\
& \mathrm{u}_{\mathrm{i},}, \mathrm{v}_{\mathrm{i}}=\mathrm{o}, \mathrm{i}=1, \ldots, \mathrm{s}, \mathrm{j}=1, \ldots, \mathrm{r}
\end{aligned}
$$

A total of 12 evaluation units were the treatments, and the productivities of carrot and cowpea-vegetable were used as outputs. To evaluate the yield of each plot, it was assumed that each plot 
utilized a single resource with a unitary level, since the outputs incorporated the possible inputs. This model is equivalent to the additive multicriteria model, with the particularity that the alternatives themselves attribute weights to each criterion, ignoring any opinion of the eventual decision maker. That is, the DEA is used as a multicriteria tool and not as a measure of classical efficiency.

In the modeling of this study we used the profit margin as input. The efficiency of the intercropping system was also determined by the score of the canonical variable $(\mathrm{Z})$, obtained through the bivariate analysis of variance of the productivities of the cowpea-vegetable and carrot.

In order to determine the economic efficiency of the intercropping system, the following economic indicators were calculated: Gross Income (GI) was obtained through the value of production per hectare, at the price paid to the producer, at the market level in the region, in December 2013. For carrot, the value paid was $\mathrm{R} \$ 0.80 \mathrm{~kg}^{-1}$ of roots and for cowpea-vegetable was $\mathrm{R} \$ 6.00 \mathrm{~kg}^{-1}$ of grains. Net Income (NI) was obtained through the difference between the gross income (GI) and the total costs (TC) involved in obtaining it. Rate of Return is the ratio of GI to TC refers to how many reals are obtained for each real applied in the evaluated intercropping system. The Profit Margin (PM) was obtained by the ratio between NI and GI, expressed as a percentage.

Univariate analyses of variance were performed on the variables determined through the statistical package SISVAR (FERREIRA, 2011) for the complete randomized complete block design with treatments arranged in a factorial scheme. The Tukey test at the 5\% probability level was used to compare the means of the spatial arrangements of the component cultures. The adjustment procedure of response curves was performed on each variable as a function of the population densities through Table Curve software (JANDEL SCIENTIFIC, 1991).

\section{RESULTS AND DISCUSSION}

\section{Agroeconomic efficiency indices}

There was no significant interaction between the spatial arrangements and population densities of cowpea-vegetable for land equivalent ratios of carrot, cowpea or the system, the $\mathrm{Z}$ score or for PEI. However, there were significant differences between the spatial arrangements for these analyzed variables (Table 1).

Table 1. Land equivalent ratios of carrot $\left(L_{E R}\right)$, cowpea-vegetable $\left(L_{E R}\right)$ and of the system (LER), score of the canonical variable $(\mathrm{Z})$, and productive efficiency index (PEI) of the carrot and cowpea-vegetable intercropping as a function of spatial arrangements.

\begin{tabular}{clllll}
\hline Spatial & \multicolumn{5}{c}{ Variables analyzed } \\
\cline { 2 - 5 } Arrangements & $\mathbf{L E R}_{\mathbf{c}}$ & $\mathbf{L E R}_{\mathbf{c v}}$ & $\mathbf{L E R}$ & $\mathbf{Z}$ & PEI \\
\hline $2 \mathrm{C}: 2 \mathrm{~F}$ & $2.40 \mathrm{a} *$ & $0.19 \mathrm{a}$ & $2.59 \mathrm{a}$ & $1.23 \mathrm{a}$ & $0.82 \mathrm{a}$ \\
$3 \mathrm{C}: 3 \mathrm{~F}$ & $2.04 \mathrm{~b}$ & $0.12 \mathrm{~b}$ & $2.16 \mathrm{~b}$ & $0.92 \mathrm{~b}$ & $0.67 \mathrm{~b}$ \\
$4 \mathrm{C}: 4 \mathrm{~F}$ & $2.12 \mathrm{ab}$ & $0.18 \mathrm{ab}$ & $2.30 \mathrm{ab}$ & $1.11 \mathrm{ab}$ & $0.73 \mathrm{ab}$ \\
\hline
\end{tabular}

*Means followed by different lowercase letters in the column differ statistically from each other according to the Tukey test at the $5 \%$ probability level.

Excluding the LER of the cowpea-vegetable, it was verified that the LER of carrot and the system were higher than 1 (one), showing agronomic superiority to single crop cultivations, by the favorable use of environmental resources in all spatial arrangements, with the $2: 2$ arrangement standing out. This maximum value obtained from LER means that the single crop requires 1.59 hectares to produce the equivalent production of the intercropping system in one hectare. When the indices were observed for the differentiated partitions of each culture, the carrot contributed 2.40 and the cowpea-vegetable supplemented with 0.19 in the 2:2 arrangement. According to Bezerra Neto et al. (2010), the species with the highest values of partial LER are considered more competitive for the growth limiting factors than the species with lower values of partial LERs.

The results of these indices indicate in intercropping there was better use of environmental resources and a biological advantage in the production. Favacho (2015), when investigating the agronomic efficiency of intercropping of carrot with cowpea-vegetable, as a function of roostertree quantities and spatial arrangements, verified that the LERs of the various systems were larger than one (the unit). An intercrop is considered efficient when the LER value is higher than 1.0, provided that the commercial pattern of the crops is reached (BEZERRA NETO et al., 2012). LER values higher than 1.0 were also obtained in intercropping systems between leafy-vegetables and/or leafy-vegetable and tubers, such as carrot and lettuce (ALMEIDA et al., 2015; BEZERRA NETO et al., 2007), arugula and coriander (MOREIRA, 2011), and carrot and arugula (LIMA et al., 2010).

The complementarity nature of the crops involved in the intercropping system can be 
considered when the yield of the intercropping is higher than that obtained from an area planted with single crops, thus indicating a biological advantage in the process of intercropping (BEZERRA NETO et al., 2007).

The observed LER values are in agreement with those obtained by Costa (2014), which showed the complementarity nature of carrot and cowpea cultures in an intercropping system. The best results of intercropping can be achieved when species are evaluated in the presence of companion plants when they strengthen the degree of complementarity and, in this case, produce more than the respective single crops (MONTEZANO; PEIL, 2006).

The highest efficiency values of the carrot intercropping with the cowpea-vegetable determined through the $\mathrm{Z}$ score and the PEI as a function of the spatial arrangements were found to be 1.23 and 0.82 , respectively, for the spatial arrangement $2: 2$, which
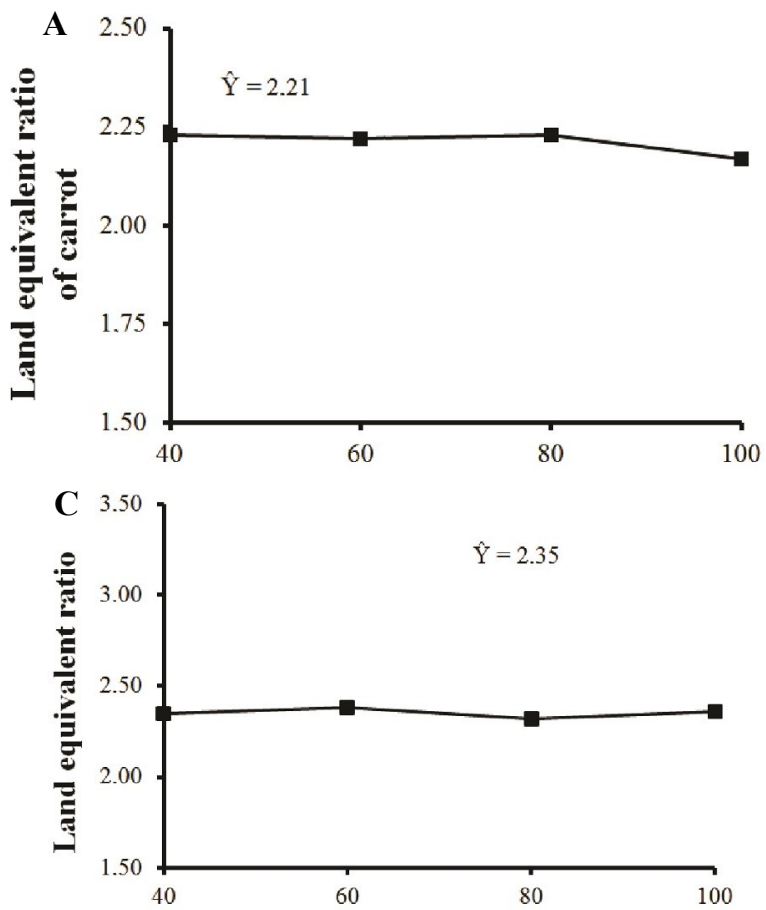

Population densities of cowpea-vegetable (\%RPSC)

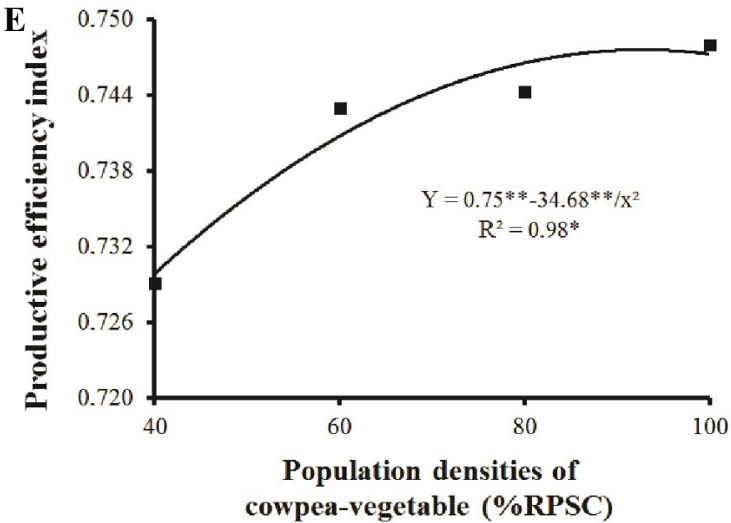

Figure 1. Land equivalent ratio for carrot (A), cowpea-vegetable (B), and system (C), score of the canonical variable Z (D), and productive efficiency index (E) of the intercropping of carrot with cowpea, as a function of the population densities of the cowpea-vegetable. stood out from the others. This result is due to the fact that the intercropping presented less competition among the crops.

Bezerra Neto et al. (2007) studied the biological productivity in carrot and lettuce intercropping systems evaluated using agroeconomic indicators, and multicriteria and DEA methods, and observed agronomic (productivity and environment) and economic (financial yields) advantages in all intercrops of carrot and lettuce.

It was not possible to adjust any response equation for the LER of carrot in the intercropping system as a function of the population densities of the cowpea-vegetable (Figures 1A and 1C). However, there was an adjustment of the response equation for the LER of cowpea, $\mathrm{Z}$ score and PEI, as a function of the population densities of the cowpeavegetable (Figures 1B, 1D and 1E).

\section{B}
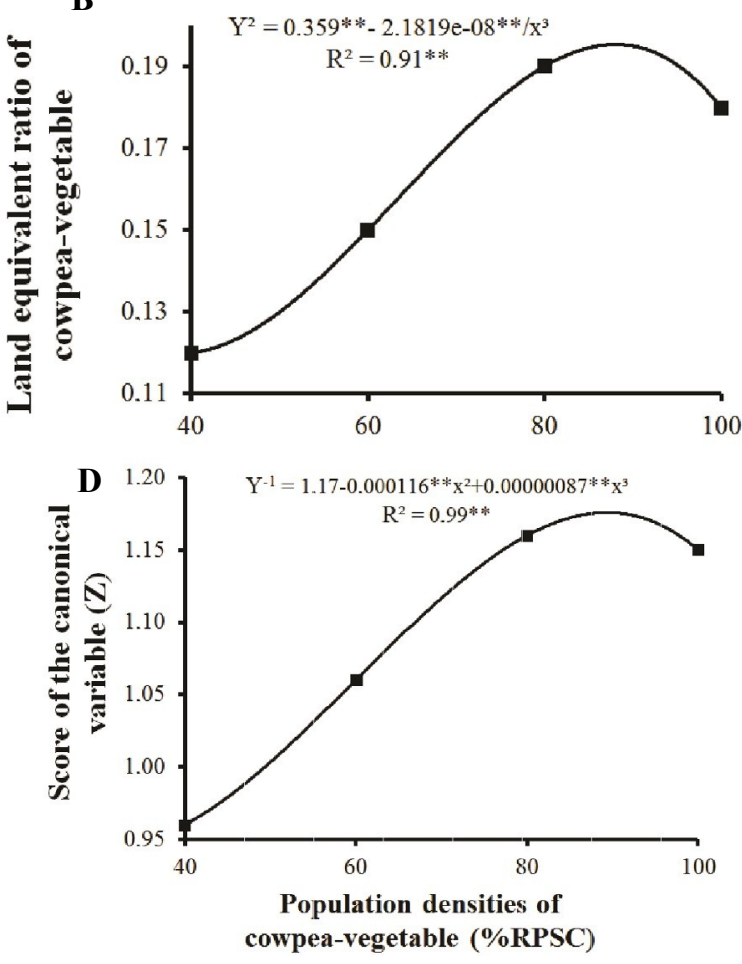
It was observed that the $\mathrm{LER}_{\mathrm{cv}}$ and the $\mathrm{Z}$ score increased with increasing population densities of cowpea, up to maximum values of 0.18 and 1.16 at densities of $40 \%$ and $90 \%$ of the RPSC, respectively, before then decreasing to the last population density (Figures 1B and 1D). This result can be attributed to the fact that the intercropping of carrot with cowpea responds to the fertilization achieved with the roostertree and to the better use of environmental resources by the crops.

Regarding the PEI, it was observed that as the population density of the cowpea increased the PEI increased to a maximum value of 0.75 , at the population density of $100 \%$ of the cowpea RPSC (Figure 1E).

\section{Economic indicators}

There was no significant interaction between the spatial arrangements and population densities of the cowpea for GI, NI, RR and PM. However, when these variables were analyzed as a function of the spatial arrangements, significant differences were observed with the spatial arrangements, whereby the 2:2 arrangement stood out from the others (Table 2).

Table 2. Gross income (GI), net income (NI), rate of return (RR) and profit margin (PM) of the intercropping of carrot with cowpea, as a function of spatial arrangements.

\begin{tabular}{|c|c|c|c|c|}
\hline \multirow[b]{2}{*}{$\begin{array}{c}\text { Spatial } \\
\text { Arrangements }\end{array}$} & \multicolumn{4}{|c|}{ Variables analyzed } \\
\hline & $\begin{array}{c}\text { GI } \\
\left(\mathrm{R} \$ \mathrm{t} \mathrm{ha}^{-1}\right) \\
\end{array}$ & $\begin{array}{c}\text { NI } \\
\left(\mathrm{R} \$ \text { t ha }^{-1}\right) \\
\end{array}$ & $\mathbf{R R}$ & $\begin{array}{l}\mathbf{P M} \\
(\%)\end{array}$ \\
\hline $2 \mathrm{C}: 2 \mathrm{~F}$ & $26,015.59 \mathrm{a}^{*}$ & $10,998.31 \mathrm{a}$ & $1.64 \mathrm{a}$ & $42.26 \mathrm{a}$ \\
\hline $3 \mathrm{C}: 3 \mathrm{~F}$ & $21,348.54 \mathrm{~b}$ & $5,580.11 \mathrm{~b}$ & $1.36 \mathrm{~b}$ & $25.19 \mathrm{~b}$ \\
\hline $4 \mathrm{C}: 4 \mathrm{~F}$ & $23,115.09 \mathrm{ab}$ & $7,302.93 \mathrm{ab}$ & $1.46 \mathrm{ab}$ & $30.75 \mathrm{ab}$ \\
\hline
\end{tabular}

*Means followed by different lowercase letters in the column differ statistically from each other according to the

Tukey test at the $5 \%$ probability level.

These indices indicate that the agronomic superiority obtained by using the intercropping systems is translated into economic advantage. The better economic performance obtained by the $2: 2$ arrangement can be explained by the smaller inter- and intra-specific competition of the component cultures.

The RR (1.64) and the PM (42.26\%) indicate the superiority of the $2: 2$ spatial arrangement, implying that for each $\mathrm{R} \$ 1.00$ invested in the intercropping of carrot and cowpea in a 2:2 arrangement, there is a return of $\mathrm{R} \$ 1.64$; or, in terms of economic advantage, a profitability of $42.26 \%$. Paula (2011) also observed this performance of the spatial arrangement 2:2 in the intercropping systems of carrot and arugula fertilized with hairy woodrose.

The data from this research corroborate those found by Moreira (2011), who identified greater incomes in the 2:2 arrangement. On the other hand, Fernandes (2012), working with the intercropping of carrot with coriander with different amounts of hairy woodrose and different spatial arrangements, found that the $4: 4$ arrangement at $15 \mathrm{t} \mathrm{ha}^{-1}$ had the best economic efficiency. For the intercropping of vegetable crops, there are several reports of reduced production costs and an increase in net revenue when compared to the sole crops, regardless of the better use of labor and natural resources, and decrease and rational use of non-renewable inputs (REZENDE et al., 2006; SILVA et al., 2008).

It was not possible to adjust any response equation for the variables analyzed as a function of the population densities of the cowpea-vegetable (Figures 2A, 2B, 2C and 2D). However, in terms of absolute values it is observed that the GI increased as the population density increased (Figure 2A). As for net income, this increased with the population density to some extent ( $80 \%$ of the RPSC) and there was a decrease later (Figure 2B). In absolute terms, this combination demonstrates greater agroeconomic efficiency.

Similar behavior was observed for the PM, which had a maximum value under the scenario of the population of $80 \%$ of RPSC (Figure 2D). The RR was found to decrease as the population density increases, indicating high competition with increasing population density (Figure 2C). 

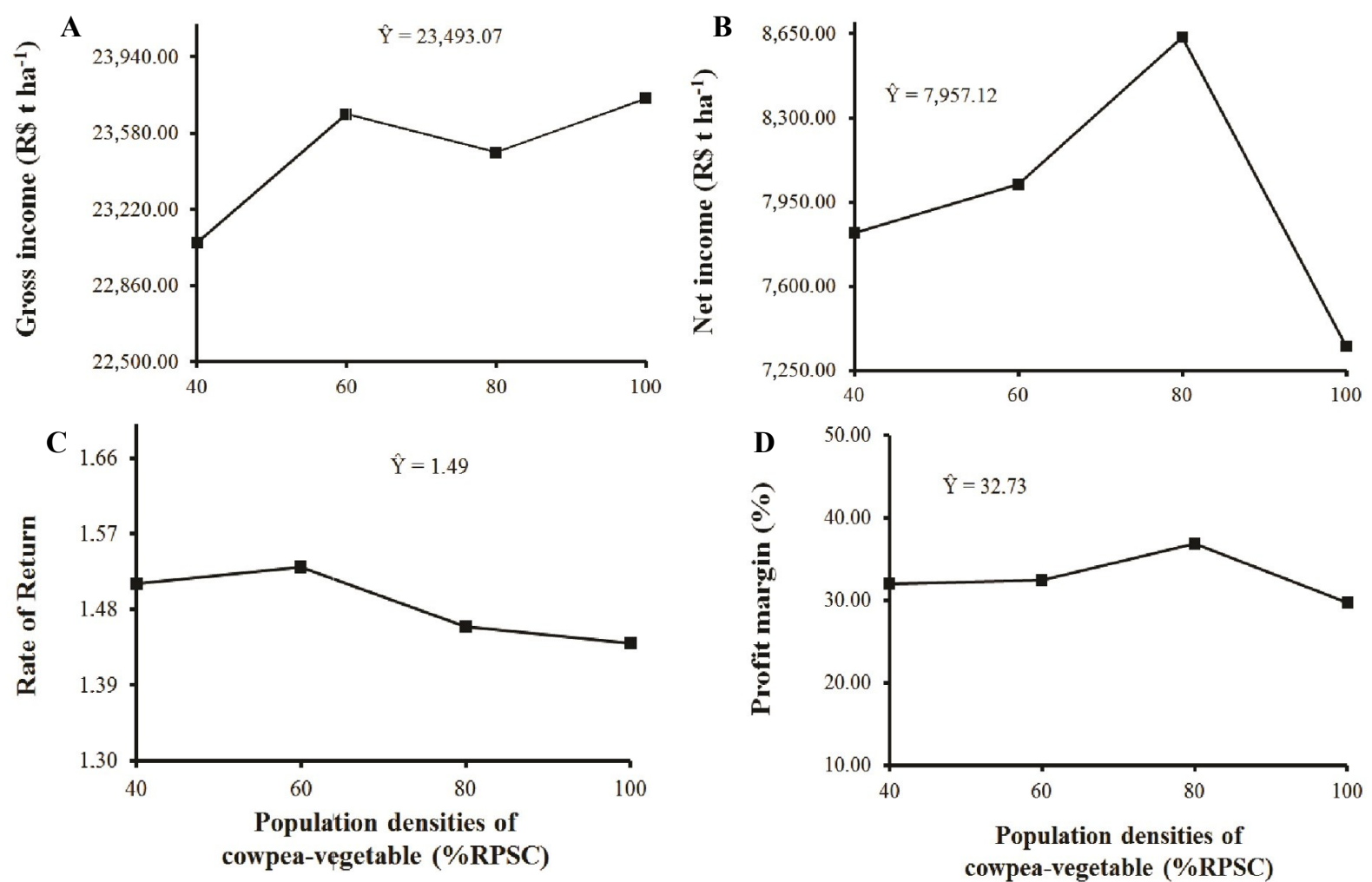

Figure 2. Gross income (A), net income (B), rate of return (C), and profit margin (D) of the intercropping of carrot with cowpea-vegetable, as a function of population densities of cowpea.

\section{CONCLUSION}

The agroeconomic efficiency of the intercropping system of carrot with cowpea-vegetable was influenced by the spatial arrangements, with the $2: 2$ arrangement standing out from the others as good.

The greatest agroeconomic efficiency of the intercropping of carrot with cowpea-vegetable was obtained with a population density of $100 \%$ of the RPSC, when the value of the PEI was 0.75 .

\section{ACKNOWLEDGEMENTS}

Special thanks are due to the Coordenação de Aperfeiçoamento de Pessoal de Nível Superior for financial support to this research and to the research group of the Plant Science Department of the Universidade Federal do Semi-Árido (UFERSA), which develops technologies for growing vegetables on family farms.

\section{REFERENCES}

ALFA, A. J.; MUSA, U. T. Assessing the land equivalent ratio (LER) and stability of yield of two cultivars of sorghum (Sorghum bicolor L. Moench)-soyabean (Glycine max L. Merr) to row intercropping system. Journal of Biology,
Agriculture and Healthcare, Tehran, v. 5, n. 18, p. 144-149, 2015.

ALMEIDA, A. E. S. et al. Eficiência agronômica do consórcio alface-rúcula fertilizado com flor-de-seda. Revista Caatinga, Mossoró, v. 28, n. 3, p. 79-85, 2015.

BATISTA, M. A. V. et al. Atributos de solo-planta e de produção de beterraba influ-enciados pela adubação com espécies da Caatinga. Horticultura Brasileira, Brasília, v. 34, n. 1, p. 12-19, 2016.

BEZERRA NETO, F. et al. Desempenho de sistemas consorciados de cenoura e alface avaliados através de métodos uni e multivariados. Horticultura Brasileira, Brasília, v. 25, n. 4, p. 514-520, 2007.

BEZERRA NETO, F. et al. Evaluation of yield advantage indexes in carrot-lettuce intercropping systems. Interciencia, Caracas, v. 35, n. 1, p. 59-64, 2010 .

BEZERRA NETO, F. et al. Assessment of agroeconomic indices in polycultures of lettuce. rocket and carrot through uni- and multivariate approaches in semi-arid Brazil. Ecological Indicators, Amsterdam, v. 14, n. 1, p. 11-17, 2012.

BEZERRA NETO, F.; GOMES, E. G.; OLIVEIRA, A. M. Produtividade biológica em sistemas consorciados de cenoura e alface avaliada através de 
indicadores agroeconômicos e métodos multicritério. Horticultura Brasileira, Brasília, v. 25, n. 3, p. 193-198, 2007.

CECÍLIO FILHO, A. B. et al. Indices of bio-agroeconomic efficiency in intercropping systems of cucumber and lettuce in greenhouse. Australian Journal of Crop Science, Lismore, v. 9, n. 12 , p. 1154-1164, 2015.

COSTA, A. P. Consorciação de cultivares de caupi-hortaliça com cultivares de cenoura em sistema orgânico. 2014. 76 f. Tese (Doutorado em Fitotecnia: Área de Concentração em Agricultura Tropical) - Universidade Federal Rural do Semi-Árido, Mossoró, 2014.

COSTA, C. C. Consórcio de alface e rúcula: aspectos produtivos e econômicos. 2006. 96 f. Tese (Doutorado em Agronomia: Área de Concentração em Produção Vegetal) - Universidade Estadual Paulista, Jaboticabal-SP, 2006.

FAVACHO, F. S. Eficiência agroeconômica do consórcio cenoura $x$ caupi-hortaliça em função de quantidades de biomassa de flor-de-seda e arranjos espaciais. 2015. $73 \mathrm{f}$. Tese (Doutorado em Fitotecnia: Área de concentração em Agricultura Tropical) - Universidade Federal Rural do Semi-Árido, Mossoró, 2015.

FERNANDES. Y. T. T. Viabilidade agroeconômica do consórcio de cenoura com coentro em função de diferentes quantidades de jitirana e arranjos espaciais. 2012. $86 \mathrm{f}$. Dissertação (Mestrado em Fitotecnia: Área de Concentração em Agricultura Tropical), Universidade Federal Rural do Semi-Árido, Mossoró, 2012.

FERREIRA, D. F. Sisvar: a computer statistical analysis system. Ciência e Agrotecnologia, Lavras, v. 35, n. 6, p. 1039-1042, 2011.

FREIRE FILHO, F. R. et al. BRS Itaim: cultivar de feijão-caupi tipo fradinho. Teresina: Embrapa Meio-Norte, 2009. 4 p. (Folder).

GRISA, C.; SCHNEIDER, S. "Plantar pro gosto": a importância do autoconsumo entre famílias de agricultores do Rio Grande do sul. Revista de Economia e Sociologia Rural, Piracicaba, v. 46, n. 2, p. 481-515, 2008.

JANDEL SCIENTIFIC. Table Curve: curve fitting software. 2. ed. Corte Madera, CA: Jandel Scientific, 1991. 280 p.

LIMA, J. S. S. et al. Productive performance of carrot and rocket cultivars in strip-intercropping system and sole crops. Agrociencia, Montecillo, v. 44, n. 7, p. 561-574, 2010.

MONTEZANO, E. M.; PEIL. R. M. N. Sistemas de consórcio na produção de hortaliças. Revista Brasileira de Agrociência, Pelotas, v. 12, n. 2, p. 129-132, 2006.

MOREIRA, J. N. Consorciação de rúcula e coentro adubada com espécie espontânea sucedida pelo cultivo de rabanete. 2011. $116 \mathrm{f}$. Tese (Doutorado em Fitotecnia: Área de Concentração em Agricultura Tropical) Universidade Federal Rural do Semi-Árido, Mossoró, 2011.

OLIVEIRA, M. K. T. et al. Desempenho agroeconômico da cenoura adubada com jitirana (Merremia aegyptia). Horticultura Brasileira, Brasília, v. 30, n. 3, p. 433-439, 2012.

PAULA, V. F. S. Viabilidade agroeconômica de consórcios de cenoura e rúcula em diferentes quantidades de jitirana e arranjos espaciais. 2011. 63 f. Dissertação (Mestrado em Fitotecnia: Área de Concentração em Agricultura Tropical) - Universidade Federal Rural do Semi-Árido, Mossoró, 2011.

PORTO, V. C. N. et al. Combination of lettuce and rocket cultivars in two cultures intercropped with carrots. Horticultura Brasileira, Brasília, v. 29, n. 3, p. 404-411, 2011.

REZENDE, B. L. et al. Viabilidade da consorciação de pimentão com repolho, rúcula, alface e rabanete. Horticultura Brasileira, Brasília, v. 24, n. 1, p. 36-41, 2006.

SILVA, G. S. et al. Viabilidade econômica do cultivo de alface crespa em monocultura e em consórcio com pepino. Ciência e Agrotecnologia, Lavras, v. 32, n. 5, p. 1516-1523, 2008.

SILVA, R. C. P. Adubação verde com espécie espontânea no consórcio de cenoura e alface em bicultivo sob diferentes quantidades de biomassa e arranjos espaciais. 2014. 71 f. Dissertação (Mestrado em Fitotecnia: Área de Concentração em Agricultura Tropical) - Universidade Federal Rural do Semi-Árido, Mossoró, 2014. 